Chief Inspector, of which about 146 visits were on work not falling directly within the provisions of the Act, but within those of other statutes relating to the prevention of air pollution. The experimental programme of testing dust emissions yielded more useful information in the 30 tests made during the year, but it was again apparent that full observance of the recommended procedure for testing was scarcely practical at most works, although close approximations were mado wherever possible. Another markedly defective electrostatic precipitator was found, and again its performance was not suspect by an external instrumental indication of its operation.

To this report also is appended a brief historical account, this time dealing with the operation of the Alkali Act in Scotland during the past hundred years.

\title{
BLAST-FURNACE CEMENT IN SOUTH AFRICA
}

$\mathrm{M}$ ANY years ago it was established (in Germany) that certain slags, by-product of iron-ore smelting in blast-furnaces, if rapidly quenched from the molten state, then finely ground with an activator such as limo or Portland cement, would set and harden very much like ordinary Portland cement. This resulted in the development of a large cement industry in Europe based on waste slag, which, as a result of considerable research over the years, has greatly expanded in production and economic importance, especially in those countries concerned with an indigenous iron and steel industry.

In the case of South Africa there appears to be a basic difference between the available slag from the iron and steel industry compared with that used for cement-making elsowhere, in that the slag produced in the Republic has a much higher magnesia content than that normally used overseas. For some time cement technologists considered that the use of high magnesia slag was liable to lead to disruptive expansion in Portland cement products made from it; consequently this local slag was looked on with suspicion. However, with continuing expansion of the iron and steel industry and concomitant mounting of slag production (this is at present running at $1,200,000$ tons per annum), something drastic had to bo done to counteract the accumulation of this unwanted by-product. Research on the problem was initiated at the National Building Research Institute of the Couneil for Scientific and Industrial Research, Pretoria, and eventually it was demonstrated that this high-magnesia slag was not conducive to unsoundness and that, under prescribed conditions, a good-quality cement could be manufactured from it.

Writing in the South African Review (C.S.I.R., ref. No. R/BOU $108 ; 1963 / 64)$, Dr. N'. Stutterheim, vicepresident of the Council, briefly describes the events leading up to the now successful utilization of this slag. He says: "Discussions between the iron and steel industry, which had sponsored the research, the cement companies and the C.S.I.R, resulted in the manufacture of two types of cement: one an interground mixture of granulated slag and Portland cement clinker and the other a finely ground granulated slag which is then mixed with Portland cement in the concrete mixer on the construction site. . . . Last year about 350,000 tons of granulated slag was converted to cement; i.e., about 12 per cent of the country's cement requirements were met from this source. This is only 30 per cent of slag output whereas at least 80 per cent could be so utilized".

It is concluded that it has now been abundantly proved that it is economic to uso South African slag for cement manufacture; that by so doing capital and running costs are saved; resources of limestone and coal, otherwise required for equivalent Portland cement production, are extended; a cement possessing properties similar to those of Portland cemont, but at lower cost, is being extensively marketed; and it is in the national interest that increasing use be made of this waste slag for cement production.

H. B. Milner

\section{UPTAKE OF HYDROCARBON CARCINOGENS BY LYSOSOMES}

\author{
By DR. A. C. ALLISON and DR. L. MALLUCCl* \\ National Institute for Medical Research, London, N.W.7
}

\begin{abstract}
$\mathrm{A}$ LTHOUGH polybenzenoid hydrocarbon carcinogens have been intensively investigated since their discovery more than thirty years ago, remarkably little is known about their intracellular fate and the way by which they bring out malignant changes. In examining the localization of carcinogens, two main approaches have been used: histological examination of the fluorescence of treated tissues and chemical analysis of isolated coll constituents. The first technique has shown that, both in vivo and in vitro, hydrocarbon carcinogens are quickly taken up into small masses in the cytoplasm of cells and remain demonstrable there for several weeks ${ }^{1-5}$. The second approach has ostablished that if careful fractionations are carried out the careinogens are not found in nuclei or bound to nucleic acid but are present in cytoplasmic constituents, an appreciable proportion being bound to protein ${ }^{6-8}$. Whether hydrocarbon carcinogens become associated with particular cytoplasmic constitu* Holder of a NATO fellowship granted by the Italian National Research
Council.
\end{abstract}

ents has never been clear, and our experiments were undertaken to throw light on this problem.

Cell cultures. Cultures of four cell types were made on coverslips. Primary Macaca monkey kidney cell cultures were grown in Medium 199 (Glaxo) +10 per cent calf serum inactivated by heating at $56^{\circ}$ for $0.5 \mathrm{~h}$. Chick embryo cell cultures were maintained in tris-(hydroxymethyl)-aminomethane-Cey's medium with peptone and lactalbumin hydrolysate ${ }^{\circ}$. HoLa cells were cultured in Medium $199+5$ per cent inactivated calf serum. Macrophages were obtained without prior stimulation by intraporitoneal inoculation of $3 \mathrm{ml}$. of culture medium containing $10 \mathrm{r} . \mathrm{U}$. of heparin per $\mathrm{ml}$. into mice of strain $V S B S / N I M R$ weighing 18-20 g. After brief massage the cells were gathered, washed and dispensed in tubes containing small coverslips. The culture medium was solution $199+20$ per cent inactivated calf serum.

Carcinogens. Hydrocarbon carcinogens (9,10-dimethyl1:2-benzanthracene (DMBA) : 20-methylcholanthrene (MCA); $1: 2,5: 6$-dibenzanthracene (DBA); and $3: 4$ - 